\title{
Composition of trawl catch fauna off the mouth of the Rio Baluarte, southeastern Gulf of California
}

\author{
Juan Madrid-Vera ${ }^{1, *}$, Eva Visauta-Girbau ${ }^{2}$, Hugo Aguirre-Villaseñor ${ }^{1}$ \\ ${ }^{1}$ Instituto Nacional de Pesca, Centro Regional de Investigación Pesquera, Mazatlán, Sinaloa, Mexico \\ ${ }^{2}$ Institut de Ciències del Mar (ICM-CSIC), Psg. Marítim de la Barceloneta 37-49, 08003 Barcelona, Spain
}

\begin{abstract}
From April to December 2007, experimental trawls ( $\mathrm{n}=44,4$ to $22 \mathrm{~m}$ depth) were made off the mouth of the Rio Baluarte ecosystem (MRB) and compared to experimental trawls (n $=54,7$ to $40 \mathrm{~m}$ ) in the adjacent offshore region (AOR) from 2002 to 2007. For both ecosystems, a total of 143 species belonging to 5 phyla were collected. Fishes comprised ca. $80 \%$ of the bycatch biomass, while molluscs and echinoderms contributed $<20 \%$ bycatch. Eight species accounted for $50 \%$ of the numerical abundance: the crab Portunus asper $(11 \%)$, the Panama grunt Pomadasys panamensis ( $8 \%)$, the curvina Stellifer ericymba $(7 \%)$, the comb sand star Astropecten armatus $(6 \%)$, the fishes Orthopristis chalceus $(6 \%)$ and Larimus effulgens $(4 \%)$, and the crabs Callinectes arcuatus $(4 \%)$ and Hepatus kossmani $(3 \%)$. Species with a high or medium survival rate with respect to trawling activity were well represented in the samples, e.g. the crabs C. arcuatus, $H$. kossmani, and Euphilax robustus, the hermit crab Petrochirus californiensis, and the sea star Luidia brevispina. For the MRB and AOR, the estimated mean biomass was 2.08 and $0.72 \mathrm{t} \mathrm{km}^{-2}$, respectively. The population of the blue shrimp Litopenaeus stylirostris and white shrimp L. vannamei was composed of recruits, juveniles, spawners, and old individuals, whereas for grunts it was composed of recruits and juveniles, but rarely old individuals. The high diversity, population structure, and productivity of the studied fauna has positive effects, such as enabling the recruitment for coastal marine fisheries. This is an important reason to protect the river mouth and the adjacent shallow waters.
\end{abstract}

KEY WORDS: Gulf of California · Trawling · Bycatch · Closed season · Population structure Resale or republication not permitted without written consent of the publisher

\section{INTRODUCTION}

The analysis of the structure and dynamics of the community and its populations is a key for fisheries management in subtropical and tropical fisheries that take place in multispecies grounds. Trawl fishing may cause the capture of non-target species, the extraction of some species, habitat modification, changes in size and age composition, changes in diversity and dominance, and also may produce artificial selection caused by gear selectivity, higher biomass extraction, and possible food-web modifications (Casey \& Myers 1998, Gislason et al. 2000, Pope et al. 2000, Ye et al. 2000, Badalamenti et al. 2002, Nicholson \& Jennings 2004, Shin et al. 2005). The bycatch of shrimp trawl- ing is estimated to produce one-third of the total fishery discards in the world (Alverson et al. 1994). Fish, which are well represented in the bycatch of the tropical shrimp trawl fisheries (Pérez-Mellado \& Findley 1985, Hall 1999), have a low survival rate in contrast to crustaceans and echinoderms (Wassenberg \& Hill 1989, Hill \& Wassenberg 1990, Kaiser \& Spencer 1995).

An important approach in recent fisheries management is the change from single stock management towards ecosystem-based management. This recognizes that the exploitation of a target species may modify both its population and the inhabited community, considering that the target species interacts through competition, predation, and other biological processes. 
The interest in multispecies fisheries has been widely recognized, and some authors have suggested indicators of such good practices and solutions conducive to sustainable development of marine fisheries (Hall 1999, FAO 2003, Hall \& Mainprize 2004) which allow to perform sensitivity analyses for fishing and environmental factors (Jennings \& Kaiser 1998, Rochet \& Trenkel 2003, Shin et al. 2005). In other studies, indicators based on assessment are contrasted with periods of fishing activity, regions, or previous models (Charvet et al. 2000, Pitcher \& Preikhost 2001, Link et al. 2002, Gribble 2003, Link 2005). Jennings \& Dulvy (2005) and Rochet et al. (2005) suggested that time trends could be compared by evaluating whether the status of an ecosystem is improving or deteriorating. The results are combined within the predefined framework to provide a diagnosis. The purpose of this method is not to provide a good fit, but to decide if the ecosystem is being affected. It is suggested that the integrative community indicators have not yet been well developed and tested, so it seems reasonable to complement them by monitoring a wide selection of populations, including target and non-target species, to achieve the best possible assessment.

To indicate the influence of any trawling on a community, it is necessary to assess the richness and contribution of the taxonomic groups of the bycatch (Alverson et al. 1994, Madrid-Vera et al. 1998, Hall 1999, Beddington et al. 2007). Several studies in the Gulf of California have included the systematic description of trawl catches. The results obtained may include a thousand species of at least 5 phyla (Hendrickx et al. 1984, Amezcua-Linares 1985, Hendrickx 1985, Pérez-Mellado \& Findley 1985, Van der Heiden 1985, Van der Heiden \& Findley 1988, Broadhurst \& Kennelly 1994). The shrimp:bycatch ratio for shrimp trawl fishery in the Gulf of California was estimated between 10:1 and 10:3 on a weight basis (Hendrickx et al. 1984, Amezcua-Linares 1985, Pérez-Mellado \& Findley 1985, Arvizu-Martinez 1987, Magallón-Barajas 1987, Alverson et al. 1994, Nance \& Scott-Denton 1996). From these ratios, the annual bycatch can be assumed to be around 250 to $500 \times 10^{3} \mathrm{t}$ for the Gulf of California. For the southern Gulf of California, for 1993 to 2004, Madrid-Vera et al. (2007) reported a bycatch: shrimp ratio of $6: 1$ to $31: 1$, a fish-landed:shrimp ratio of 1:1.44 \pm 0.54 , and an annual biomass bycatch of $90 \pm 45 \times 10^{3} \mathrm{t}$.

In the present study we analyze data on species composition and biomass of bycatch of species from the shrimp trawl fishery in the mouth of the Rio Baluarte in the southern Gulf of California. We assumed that the trawl catch would produce indicators of composition and abundance of the communities and would allow us to evaluate the effects of climate and trawl fishing. Our main objectives were to develop descriptive models of species richness and describe the community composition, group associations, and the population structure of 3 commercially important species, the white shrimp Litopenaeus vannamei, the blue shrimp L. stylirostris, and the Panama grunt Pomadasys panamensis. In this way we intend to support the management of the river mouth, which is of ecological and economic importance.

\section{MATERIALS AND METHODS}

The study was conducted in nearshore waters of the southeastern Gulf of California as part of the yearly assessment of the shrimp population made by the National Fisheries Institute of Mexico (INAPESCA). Two sets of data were used: (1) off the mouth of the Rio Baluarte $\left(\mathrm{MRB}_{i} 22^{\circ} 48^{\prime} 05^{\prime} \mathrm{N}, 106^{\circ} 04^{\prime} 06^{\prime} \mathrm{W}\right.$ to $\left.22^{\circ} 49^{\prime} 11^{\prime} \mathrm{N}, 106^{\circ} 02^{\prime} 50^{\prime} \mathrm{W}\right)$, (2) from the adjacent offshore region (AOR) corresponding to INAPESCA fishing zone 40, that comprises the coastal waters off Mazatlán, Sinaloa $\left(23^{\circ} 18^{\prime} \mathrm{N}, 106^{\circ} 29^{\prime} \mathrm{W}\right)$ to Cuautla, Nayarit $\left(22^{\circ} 11^{\prime} \mathrm{N}, 105^{\circ} 45^{\prime} \mathrm{W}\right)$.

In the MRB, 44 demersal trawl hauls were made onboard artisanal boats $7.5 \mathrm{~m}$ long fitted with outboard engines of 75 to $115 \mathrm{hp}$ and a small shrimp trawl net (average door spread $6.9 \mathrm{~m}$ ), which was towed at 2 knots for $0.5 \mathrm{~h}$ trawling an area of about $1.2 \pm 0.4$ ha. Sampling was performed monthly from April to December 2007 at 4 different depths (4, 9, 15, and $22 \mathrm{~m})$. During May, June, July and August there were 2 samplings per month that were averaged.

In the AOR, 54 demersal trawl hauls were made using boats with an inboard engine (345 to $520 \mathrm{hp}$ ) and a shrimp trawl net (average door spread $34.9 \mathrm{~m}$ ), which was towed at $2.3 \mathrm{knots}$ for $1 \mathrm{~h}$ trawling an area of about $14 \pm 1.4$ ha. During the closed season (April to September) of 2002 to 2007, sampling was performed every August at 7 different depths (from 7 to $40 \mathrm{~m}$ ). The total area in the AOR, from the coastline to $83 \mathrm{~m}$ depth, is nearly $2800 \mathrm{~km}^{2}$ (Fig. 1).

For both data sets, the catch per unit effort (CPUE) of all the gear was standardized to make the tows comparable. After each tow, the biomasses of shrimp and bycatch were estimated. Bycatch and shrimp were stored separately in plastic bags labeled with the date, station number, and fishing gear used, and frozen. Bycatch fauna was identified in the laboratory.

Community species richness was analysed using the exponential model $S_{t}=\mathrm{A}\left(1-\mathrm{e}^{-b t}\right)$ and the MichaelisMenten model $S_{t}=a t /(1+b t)$. In both equations $S_{t}$ represents the number of species in the sample $t$ (for the trawled area), $b$ is the instantaneous addition rate of newly identified species to the checklist over the effort in the trawled area, and the asymptote $A$ is given by 


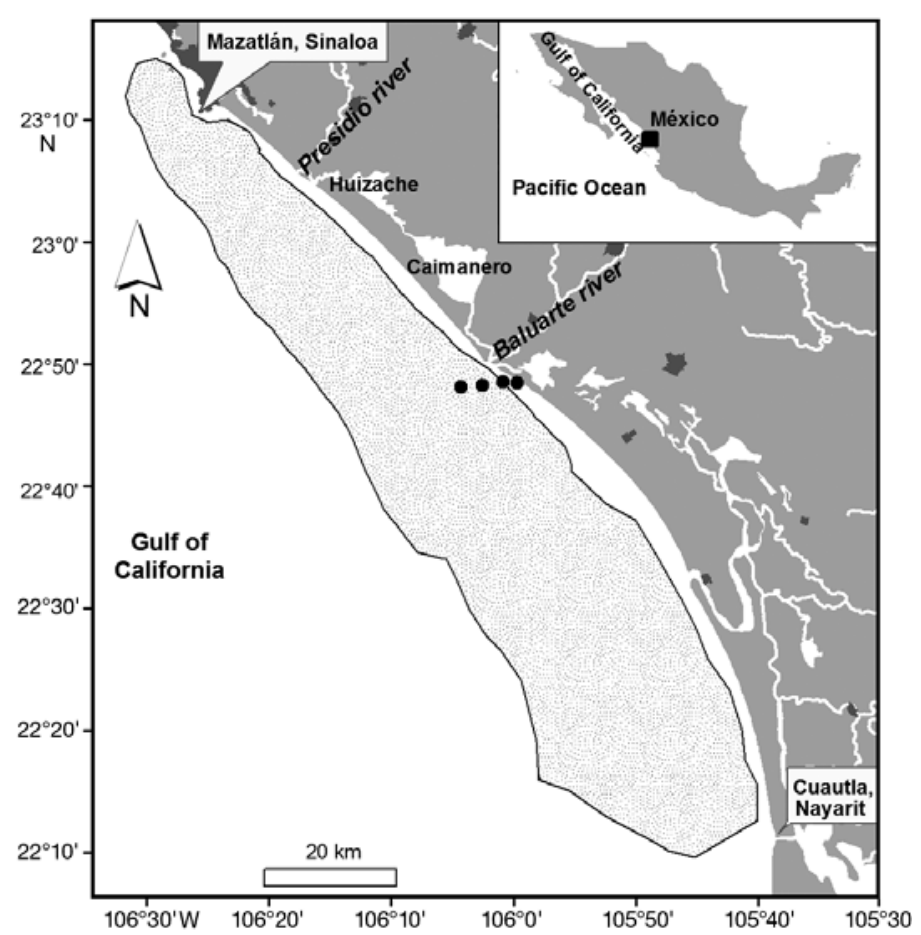

Fig. 1. Sampling stations at 4 different depths $(\bullet)$ off the mouth of the Rio Baluarte (MRB). The adjacent offshore region (AOR) where the hauls took place is stippled

$a / b$. The model parameters were estimated by minimizing the negative for log-likelihood function using Newton's direct search algorithm (Neter et al. 1996).

To estimate the confidence intervals for the parameters in the previous models, we used the likelihood profile (Venzon \& Moolgavkor 1988, Hilborn \& Mangel 1997) to determine confidence intervals for the parameters either together or individually. The confidence intervals for $n$ parameters were estimated based on the chi-square distribution with $m$ degrees of freedom (Zar 1974). For a single parameter $p$, the confidence interval is defined as all values of $p$ that satisfy the inequality:

$$
2\left[L\left(Y P_{\text {est }}\right)-L(Y P)\right]<\chi_{1,1-\alpha}^{2}
$$

where $2\left[L\left(Y P_{\text {est }}\right)\right]$ represents the negative loglikelihood of the most likely value of $p$ and $\chi_{1,1-\alpha}^{2}$ are the values of the distribution with 1 degree of freedom at a confidence level of $1-\alpha$. Hence the CI for the estimator accepts all values $\leq 3.84$ (Hilborn \& Mangel 1997).

The total bycatch for the AOR, from the coastline to $22 \mathrm{~m}$ depth, was analyzed using Monte Carlo routines (Haddon 2001). The random numbers were simulated using the inverse normal distribution $n\left(\mu, \sigma^{2}, \alpha\right)$, where $\alpha$ is a random number from 0 to 1 , and $\mu$ and $\sigma^{2}$ were estimated by generating $n=100000$ random samples.
To test differences in bycatch in the MRB, a stratified survey design was used, with depth and month as factors and biomass as the independent variable. A stratified survey design was also used to test differences in bycatch in the AOR, with depth and latitude as factors and biomass as the independent variable.

For the MRB, a matrix of species abundance in number and weight was produced, standardized to density for the trawled area (Folmer \& Pennington 2000), and scaled to total catch. For searching a gradient over time, the numerical abundance of the species was analyzed using multidimensional scaling analysis (MDS) of the Euclidian distance and the unweighted pairgroup average. Only species that were present in at least 4 mo or samples were considered.

The length-frequency distribution was analysed using multinomial analysis (Haddon 2001) for the 3 most abundant commercial species: Pomadasys panamensis, Litopenaeus vannamei, and L. stylirostris.

\section{RESULTS}

A total of 44 samples from the MRB were analyzed. The trawling area covered 39.4 ha and the total catch was $1310 \mathrm{~kg}$. For the AOR, 54 samples were analyzed from a trawling area of 756 ha and a total catch of $7700 \mathrm{~kg}$ (Table 1).

For the MRB, 37 species contributed nearly $75 \%$ to the total numerical abundance, which includes bycatch and the 2 shrimp species Litopenaeus vannamei and L. stylirostris. The most abundant species were the crab Portunus asper, the Panama grunt Pomadasys panamensis, the hollow stardrum Stellifer ericymba, and the sea star Astropecten armatus. Remarkable is the great number of species with a relatively high survival rate to trawling, such as the sea star Luidia bre-

Table 1. Basic sampling data from the mouth of the Rio Baluarte (MRB) and adjacent offshore region (AOR) in the southeastern Gulf of California. For AOR, only samples taken in August at $\leq 22 \mathrm{~m}$ were used. AT: area trawled, BB: bycatch

biomass, Mo: month, Yr: year, Trawls: number of trawls

\begin{tabular}{|c|c|c|c|c|c|c|c|}
\hline \multirow[t]{2}{*}{ Mo } & \multicolumn{3}{|c|}{$-\mathrm{MRB}-$} & \multirow[b]{2}{*}{ Yr } & \multirow{2}{*}{$\overline{\text { Trawls }}$} & \multicolumn{2}{|c|}{$-\mathrm{AOR}-$} \\
\hline & Trawls & $\begin{array}{c}\text { AT } \\
\text { (ha) }\end{array}$ & $\begin{array}{c}\text { BB } \\
(\mathrm{kg})\end{array}$ & & & $\begin{array}{l}\text { AT } \\
\text { (ha) }\end{array}$ & $\begin{array}{c}\mathrm{BB} \\
(\mathrm{kg})\end{array}$ \\
\hline Apr & 4 & 3.2 & 60 & & & & \\
\hline May & 8 & 7.6 & 188 & 2002 & 9 & 126 & 715 \\
\hline Jun & 8 & 4.2 & 175 & 2003 & 9 & 126 & 1330 \\
\hline Jul & 8 & 8 & 74 & 2004 & 9 & 126 & 1582 \\
\hline Aug & 8 & 9.2 & 254 & 2005 & 9 & 126 & 480 \\
\hline Sep & 4 & 3.6 & 545 & 2006 & 9 & 126 & 2500 \\
\hline Dec & 4 & 3.2 & 28 & 2007 & 9 & 126 & 1100 \\
\hline Total & 44 & 39.4 & 1310 & Total & 54 & 756 & 7707 \\
\hline
\end{tabular}


vispina, the crustaceans Callinectes arcuatus, Hepatus kossmani, and Euphilax robustus, and the hermit crab Petrochirus californiensis. The flatfishes Cyclopsetta querna, Citharichthys gilberti, Syacium ovale, Symphurus elongates, and Etropus crossotus have a lower survival rate (Table 2).

For the AOR, fishes (Chondrichtyes and Osteichtyes) are highly important: 509 individuals ha ${ }^{-1}$ (Fig. 2a), corresponding to a biomass of $\sim 25 \mathrm{Kg} \mathrm{ha}^{-1}$ (Fig. 2b), and a presence of 97 species (Fig. 2c). The total weight-percentage contribution of fish is almost $79 \%$, followed by crustaceans $(15 \%)$, cnidarians $(3 \%)$, echinoderms $(2 \%)$, and molluscs $(1 \%)$. Fishes are highly vulnerable to fishing activity and our results show that they represent the most catchable group.

Table 2. Species that contribute to $75 \%$ of the numerical abundance in the area off the mouth of the Rio Baluarte (MRB), southeastern Gulf of California, from May to December. Also given: taxonomic group of species, individuals per hectare, presence in number of samples

\begin{tabular}{|c|c|c|c|c|}
\hline Species & Group & Ind. ha ${ }^{-1}$ & Presence & $\%$ \\
\hline Portunus asper & Crustacea & 80 & 6 & 11.29 \\
\hline Pomadasys panamensis & Pisces & 44 & 6 & 8.47 \\
\hline Stellifer ericymba & Pisces & 77 & 4 & 6.81 \\
\hline Astropecten armatus & Echinodermata & 49 & 6 & 6.37 \\
\hline Orthopristis chalceus & Pisces & 36 & 4 & 5.73 \\
\hline Larimus effulgens & Pisces & 21 & 4 & 3.86 \\
\hline Callinectes arcuatus & Crustacea & 25 & 4 & 3.65 \\
\hline Hepatus kossmani & Crustacea & 21 & 6 & 3.40 \\
\hline Selene peruviana & Pisces & 35 & 6 & 2.90 \\
\hline Achirus mazatlanus & Pisces & 17 & 6 & 2.77 \\
\hline Arius furthi & Pisces & 19 & 3 & 2.44 \\
\hline Luidia brevispina & Echinodermata & 38 & 4 & 2.09 \\
\hline Cyclopsetta querna & Pisces & 13 & 4 & 1.45 \\
\hline Citharichthys gilberti & Pisces & 14 & 5 & 1.25 \\
\hline Sicyonia disdorsalis & Crustacea & 6 & 4 & 1.18 \\
\hline Isopisthus remifer & Pisces & 7 & 4 & 0.99 \\
\hline Diapterus peruvianus & Pisces & 7 & 4 & 0.99 \\
\hline Synodus evermanni & Pisces & 14 & 4 & 0.98 \\
\hline Centropomus robalito & Pisces & 7 & 4 & 0.79 \\
\hline Syacium ovale & Pisces & 13 & 4 & 0.78 \\
\hline Symphurus elongatus & Pisces & 12 & 5 & 0.70 \\
\hline Litopenaeus vannamei & Crustacea & 6 & 6 & 0.67 \\
\hline Ophioscion strabo & Pisces & 6 & 5 & 0.64 \\
\hline Prionotus ruscarius & Pisces & 7 & 5 & 0.63 \\
\hline Neverita reclusiana & Mollusca & 3 & 4 & 0.55 \\
\hline Peprilus medius & Pisces & 3 & 5 & 0.46 \\
\hline Litopenaeus stylirostris & Crustacea & 4 & 6 & 0.46 \\
\hline Stellifer illecebrosus & Pisces & 8 & 5 & 0.44 \\
\hline Opisthopterus dovi & Pisces & 5 & 4 & 0.40 \\
\hline Euphilax robustus & Crustacea & 4 & 6 & 0.40 \\
\hline Micropogonias ectenes & Pisces & 4 & 4 & 0.39 \\
\hline Etropus crossotus & Pisces & 3 & 5 & 0.29 \\
\hline Lolliguncula panamensis & Mollusca & 3 & 5 & 0.26 \\
\hline Pseudupeneus grandisquamis & Pisces & 2 & 5 & 0.23 \\
\hline Larimus argenteus & Pisces & 1 & 4 & 0.23 \\
\hline Eucinostomus gracilis & Pisces & 3 & 5 & 0.18 \\
\hline Petrochirus californiensis & Crustacea & 2 & 5 & 0.14 \\
\hline Total & & & & 75.25 \\
\hline
\end{tabular}

For both areas, 143 species from 5 taxonomic groups were identified: 3 Cnidaria, 20 Mollusca, 19 Crustacea, 4 Echinodermata, and 103 fish species, including 8 species of elasmobranches.

The estimated maximum richness was 216 species for the exponential model and 311 for the MichaelisMenten model (Fig. 3a). For both models, the best fit for the parameter precision is shown in Fig. 3b,c and Fig. 3d,e, respectively.

For the MRB, the total mean biomass was $2.08 \mathrm{t} \mathrm{km}^{-2}$ and, with the exception of September, the total mean biomass was $<4 \mathrm{t} \mathrm{km}^{-2}$. In September 2007 there was an increase to $10.3 \mathrm{t} \mathrm{km}^{-2}$. This maximum is evident when comparing September (end of closed season) with December (3 mo after the start of the fishing season). In total, the cumulative function indicates a surplus biomass that increased to $17.7 \mathrm{t} \mathrm{km}^{-2}$ (Fig. 4b). The random model fluctuation is shown for each month, without remarkable outliers (Fig. 4c). The data with values below the mean and the 0.68 standard deviation were 0.61 for May, 0.61 for June, 0.6 for July, 0.62 for August, 0.66 for September, and 0.62 for December, when the maximum fitted criteria is $\geq 0.68$.

For the AOR, the bycatch biomass ranged from 0.35 to $1.49 \mathrm{t} \mathrm{km}^{-2}$ and the total mean was $0.72 \mathrm{t} \mathrm{km}^{-2}$, with the values recorded in 2002, 2005, and 2007 $\leq 0.72 \mathrm{t} \mathrm{km}^{-2}$, whereas those in 2003, 2004 , and 2006 were $\geq 0.72 \mathrm{t} \mathrm{km}^{-2}$. The model produced a maximum of $1.49 \mathrm{t}$ $\mathrm{km}^{-2}$ in August 2006, double the total mean (Fig. 5). In the cumulative function, the value obtained was $4.3 \mathrm{t} \mathrm{km}^{-2}$ for 2002 to 2007 (Fig. 5b), which is an indicator of the important biomass surplus for the regional fisheries. The random fluctuation model showed no remarkable outliers in any year. The quantity of data under the mean and a 1.96 standard deviation was 0.60 for 2002, 0.56 for 2003, 0.59 for 2004, 0.66 for 2005, 0.61 for 2006, and 0.64 for 2007 (Fig. 5c).

Other results for the MRB data set were obtained from multivariate analysis of the community using only the species that were present in at least 4 mo. In Fig. 6, we can see a well-developed group from June to September and 2 isolated months December and May. The value for the stress $<0.05$ is 
associated with a good representation of association of either sample.

The total length (TL) values for 340 grunts Pomadasys panamensis were 5 to $335 \mathrm{~mm}$. From the graphical analysis of 15 cohorts (Fig. 7 a) only 7 (85, 110, 125, 250, 280, 300, $295 \mathrm{~mm}$ ) were well represented, whereas the other 9 were inconspicuous.

The TL values for 218 white shrimp Litopenaeus vannamei were 80 to $270 \mathrm{~mm}$. From the graphical analysis of 11 cohorts (Fig. $7 b)$ only 8 (110, 125, 135,

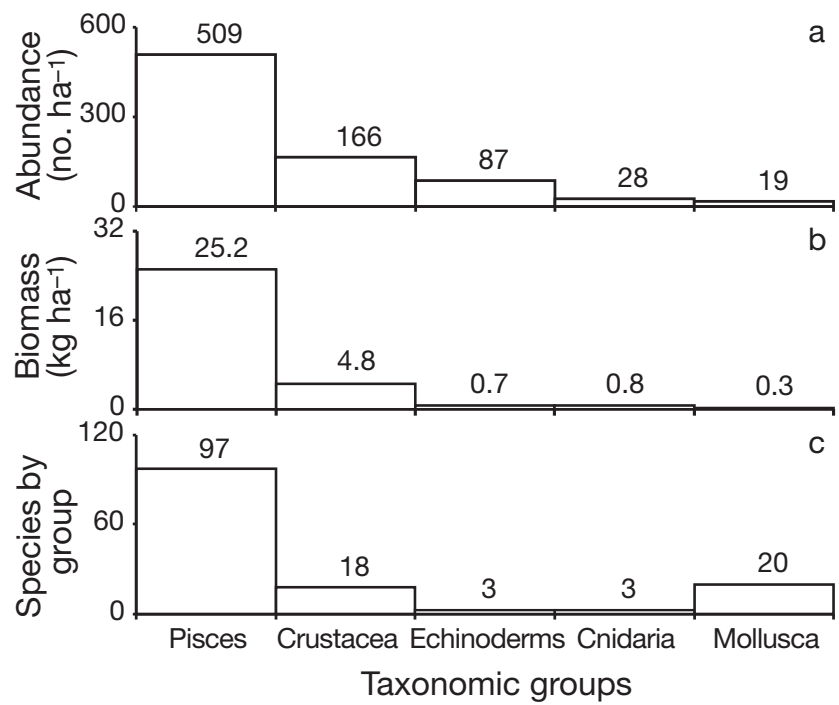

Fig. 2. (a) Abundance, (b) biomass per hectar, and (c) species by taxonomic group for the fauna off the mouth of the Rio Baluarte from May to December 2007
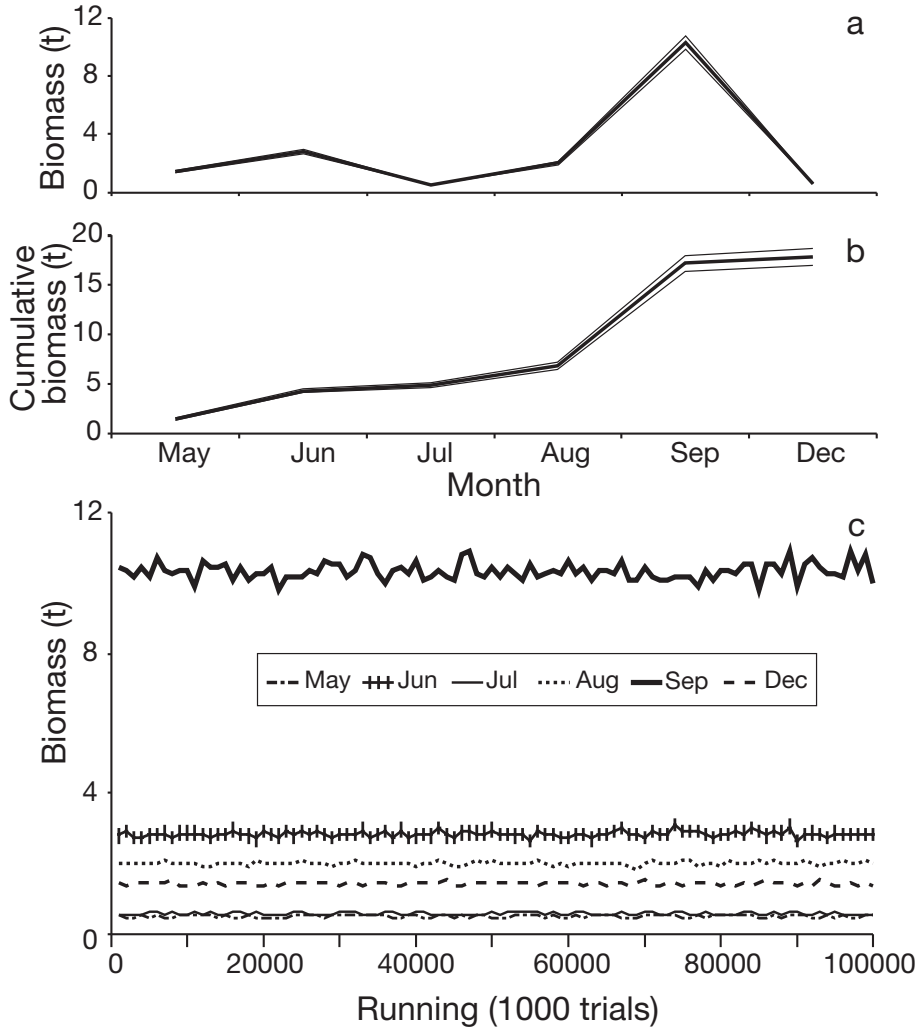

Fig. 4. (a) Generated biomass (catch in $\mathrm{t}$ per $\mathrm{km}^{2}$ ) and (b) cumulative biomass from the central tendencies (bold line) and $\pm 1.96 \mathrm{SD}$ of dispersion (thin line) for the area off the mouth of the Rio Baluarte. (c) A simulated random sample from the population in 100000 trials for each month from May to December 2007. The $\mathrm{x}$-axis shows the number of trials (e.g. 20000 represents 20 runnings of 1000 trials)
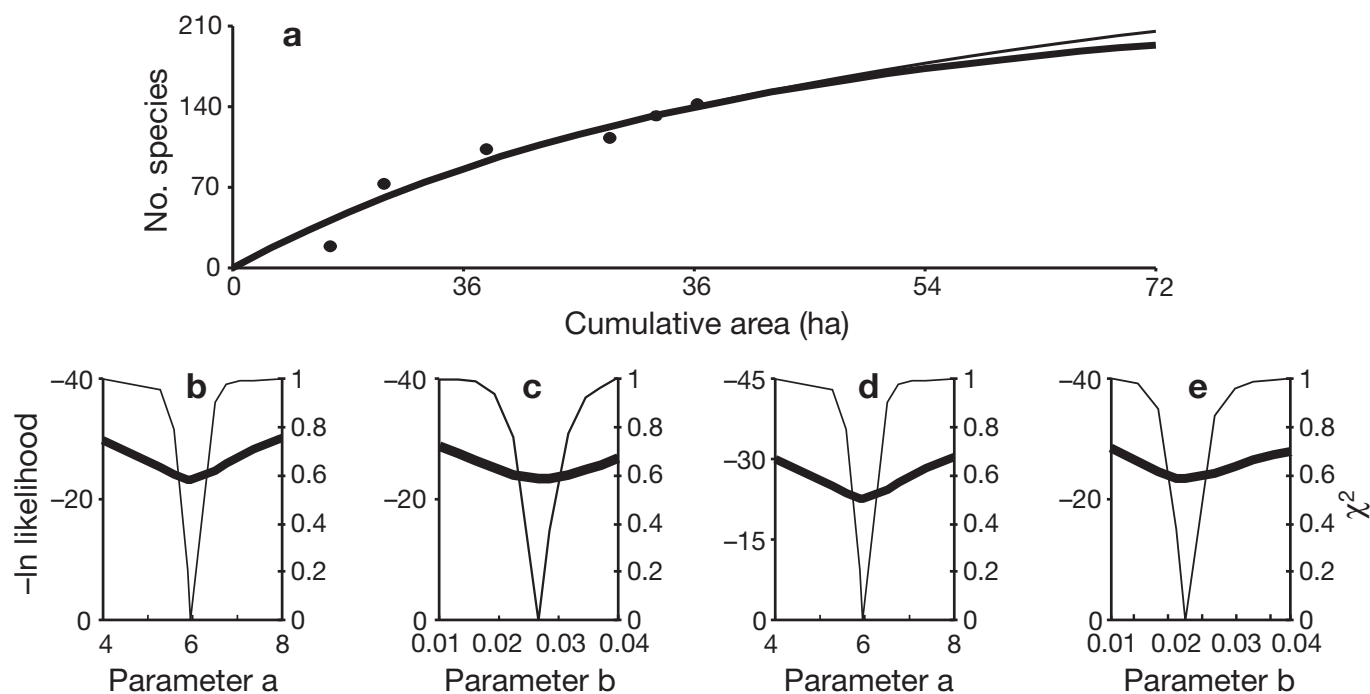

Fig. 3. (a) Species richness curves of the community off the mouth of the Rio Baluarte, according to trawling data. Both exponential (thin line) and Michaelis-Menten models (bold line) were used. The addition rate of newly identified species of the checklist over effort in the trawled area was used. In both cases the parameter precision is shown for the (b, c) exponential model and (d, e) the Michaelis-Menten model. The thin line is the negative log-likelihood profile $(-\ln \mathrm{L})$ and the bold line is the $\chi^{2}$ probability profile 

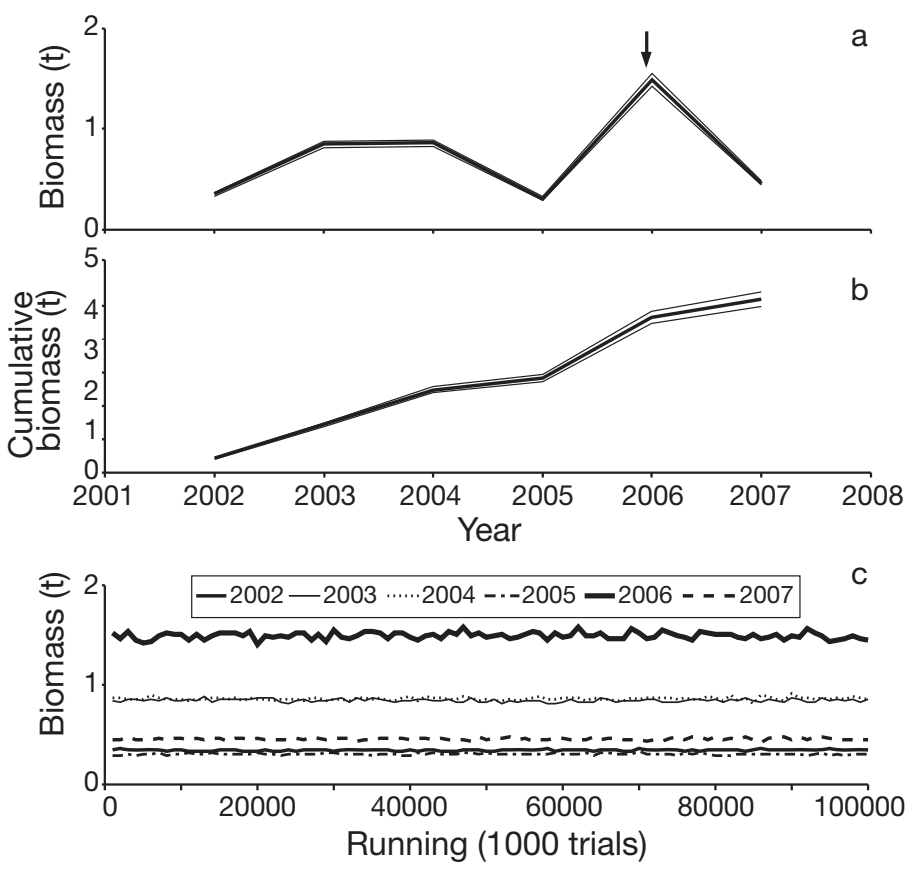

Fig. 5. (a) Generated biomass (catch in $\mathrm{t}$ per $\mathrm{km}^{2}$ ) and (b) cumulative biomass from the central tendencies (bold line) and $\pm 1.96 \mathrm{SD}$ of dispersion (thin line) from the adjacent offshore region. (c) A simulated random sample from the population in 100000 trials for each year in the period 2002 to 2007 .

The arrow indicates the El Niño Southern Oscillation

$160,175,195,215,225 \mathrm{~mm})$ were well represented, whereas the other 3 were inconspicuous. The first 3 groups were recruits, groups 4 to 6 were mature, and groups 7 and 8 were spawners.

The TL values for 148 blue shrimp Litopenaeus stylirostris were 115 to $275 \mathrm{~mm}$. From the graphical analysis of 11 cohorts (Fig. 7c) only $9(140,155,165$, $175,185,200,225,240,250 \mathrm{~mm})$ were well represented, whereas the other 2 were inconspicuous. The first 2 groups were recruits, groups 3 to 5 were mature, and groups 6 to 9 were spawners.

\section{DISCUSSION}

The sampling power of the trawling gear was analyzed by using the richness curves. Sampling totaled to a richness of 143 species, which was $89 \%$ of the maximum predicted by the exponential model and $62 \%$ of the maximum predicted by the Michaelis-Menten model. Owing to the percentage obtained, we can conclude that this study has generated plausible information about the fauna off the river mouth of the Rio Baluarte.

For the MRB, the analysis of the taxonomic groups shows the importance of fishes $(79 \%$ of total bycatch

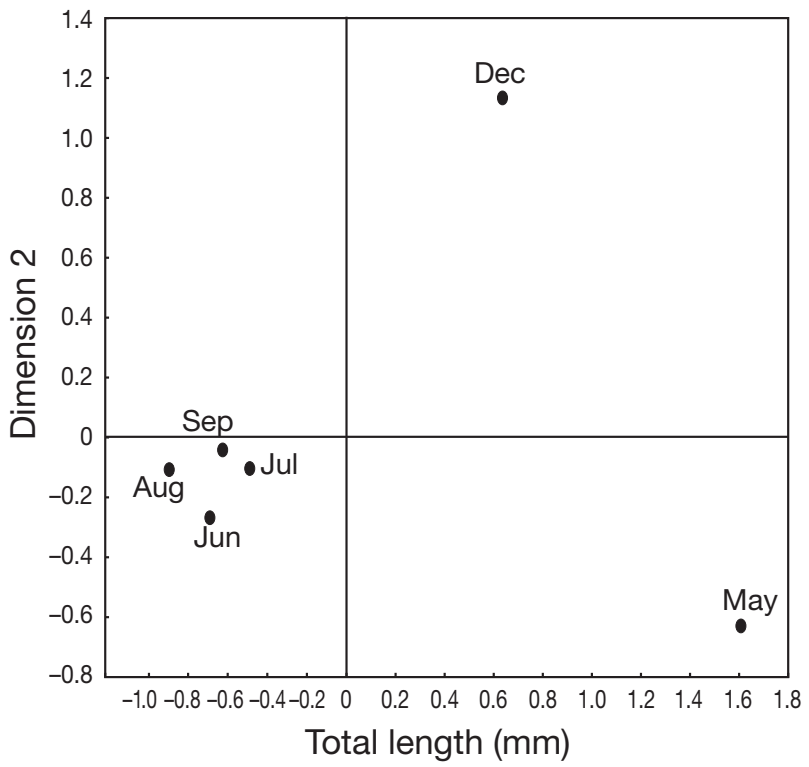

Fig. 6. Multidimensional scaling plot for the community using the species recorded in at least 4 mo. The matrix was produced from the Euclidian distance and the grouping was the unweighted pair-group average. The plot shows 2 single months and a cluster of 4 months clearly associated with a climate gradient. A stress value $<0.05$ is associated with a good representation of the samples association. Stress $=0.0000027$

biomass), whereas molluscs and echinoderms contributed $<20 \%$. Similar results were found by MadridVera et al. (2007) in 2 nearby areas, the inshore area of Mazatlán and Teacapán.

For the AOR, the analysis of the taxonomic groups also shows the importance of fishes, with 509 individuals $\mathrm{ha}^{-1}$, a biomass of $\sim 25 \mathrm{~kg}$, and a total of 97 species. Fishes are a vulnerable group with a high catch rate to trawling (Hendrickx et al. 1984, Pérez-Mellado \& Findley 1985, Wassenberg \& Hill 1989, Hill \& Wassenberg 1990, Alverson et al. 1994, Stobutzki et al. 2001). In a regional trawling catch survey between 22 and $26^{\circ} \mathrm{N}$, Madrid-Vera et al. (2007) reported 250 species of fish; some of the abundant species were similar to those found in the present study, such as the grunt Orthopristis chalceus, the pacific moon fish Selene peruviana, the Panama grunt Pomadasys panamensis, and Synodus spp. Using information from a variety of literature sources (de Groot 1984, Kaiser \& Spencer 1994, Kaiser \& Spencer 1995, Hill et al. 1999, de Juan et al. 2007), we considered 4 levels of survival to capture: high, mean, low, and none. There is a remarkable presence of species with a low survival rate, such as the flatfishes Cyclopsetta querna, Citharichthys gilberti, Syacium ovale, Symphurus elongatus, and Etropus crossotus. Other studies in the same area showed similar faunal groups that were obtained with similar fishing gear (Hendrickx et al. 1984, Hendrickx 1985). 

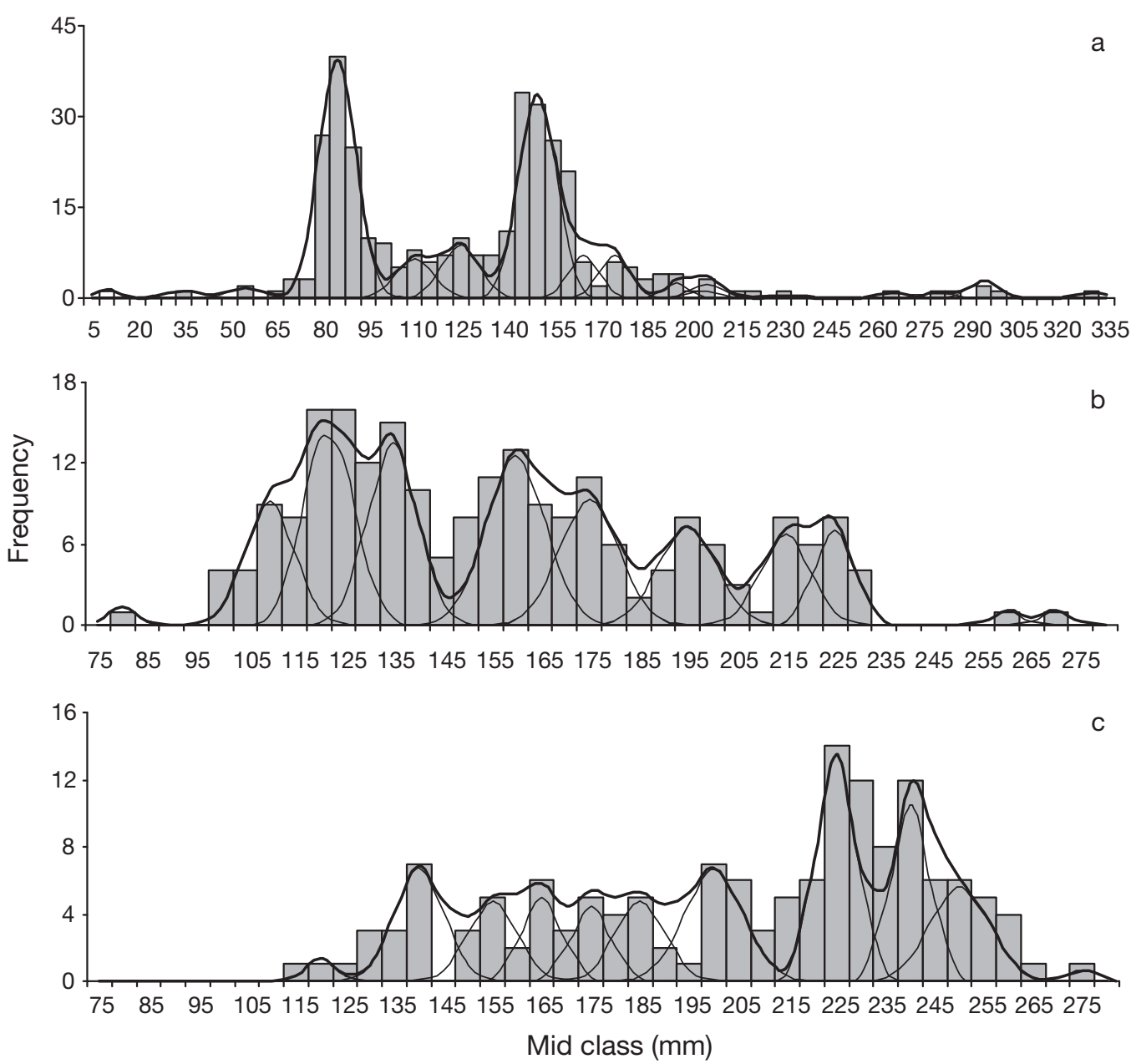

Fig. 7. Total length distribution and multinomial analysis for (a) the Panama grunt Pomadasys panamensis, (b) the white shrimp Litopenaeus vannamei, and (c) the blue shrimp L. stylirostris, sampled in the area off the mouth of the Rio Baluarte. Bars: observed data. Lines show results of multinomial analysis - thin lines: cohorts; thick lines: total

For the AOR, crustaceans were the second most important group in individual number and total weight per area, even though the species number can be higher, as shown in other studies (Hendrickx et al. 1984, Hendrickx 1985). The crustaceans with high and medium survival rates, including the crabs Portunus asper, Callinectes arcuatus, Hepatus kossmani, Petrochirus californiensis, and Euphilax robustus appear as an important group in our data. They contribute $75 \%$ to the abundance of the crustacean group. By individual number per area, echinoderms are the third most important group. In the present study we found only 3 species, but the number of species caught by trawling can reach 13, as has been reported from a previous study in the region (Caso 1976) The echinoderm species caught in the present study have a high survival rate to trawling. By both individual number and total weight in relation to species, the mollusc contribution is small and may be related to the selectivity of the fishing gear.
The bycatch biomass for August 2007 was $0.46 \mathrm{t} \mathrm{km}^{-2}$ $\mathrm{yr}^{-1}$ for the experimental trawl in the MRB and $2 \mathrm{t} \mathrm{km}^{-2}$ $\mathrm{yr}^{-1}$ for the trawl in the AOR. The generated bycatch biomass for the MRB in September 2007 was $10 \mathrm{t} \mathrm{km}^{-2}$ $\mathrm{yr}^{-1}$. For the Laguna Huizache-Caimanero, the input data for an Ecopath model (Zetina-Rejón et al. 2003, Pinnegar \& Polunin 2004), which includes organisms potentially accessible to trawl fishing but does not consider zooplankton, phytoplankton, macrophytes, or detritus, resulted in a general biomass of $59.3 \mathrm{t} \mathrm{km}-2$ $\mathrm{yr}^{-1}$. The sum of exports (fishery catch), referent to the Ecopath model, was $7.4 \mathrm{t} \mathrm{km}^{-2} \mathrm{yr}^{-1}$. The input data used in the Ecopath model were taken from studies made in the coastal lagoon during the 1970s and the fishery catch was given for 1984 to 1986. In general, results from the present study were congruent with those from other models, even though the previous models used for the lagoons are not calibrated and do not have a robust reference framework. 
Analysis of the population structure of grunts allowed us to deduce numerous cohorts. Recruits and juveniles were well represented, and there was a large presence of old individuals. For white shrimp there were also numerous cohorts, with good representation of recruits, mature individuals, and spawners, and the biggest individual recorded was $265 \mathrm{~mm}$, which is big according to the literature references on longevity and size. For blue shrimp, it was also possible to deduce numerous cohorts, including large recruits $(\geq 140 \mathrm{~mm})$, which may be because recruitment occurred before the present study (INP 2007). The other cohorts were mature individuals, spawners, and old individuals $>265 \mathrm{~mm}$. The length-frequency distributions of these 3 species indicate the presence of a greater number of juveniles in shallow waters (MRB), with a larger number of shrimp spawners during the closed season.

The high diversity, population structure, and productivity that cause positive effects on recruitment for marine and lagoon fisheries are important for the protection of the mouth of and the shallow waters off the Rio Baluarte. The closure of fishing in the river mouth is already included in the shrimp management plan, with rules to protect the shrimp species mentioned in this study. However, a revision of these management tools is necessary for the ecosystem and its fisheries to be functional and sustainable.

Acknowledgements. The authors thank Dr. E. Glazier for editing this English-language text and his helpful comments. The authors are grateful for the suggestions and comments by anonymous referees which improved the manuscript. Thanks to M. C. Ramirez for the facilitation of the bibliographic references and to Ricardo Meraz for help with maps. We thank all the participants and fishermen who helped with the sampling at Laguna Huizache-Caimanero. This work was funded by the National Fisheries Bureau as part of the yearly assessment of the shrimp population. E. Visauta was supported by a fellowship of Ministerio de Asuntos Exteriores (MAE-AECI).

\section{LITERATURE CITED}

Alverson DL, Freeberg MH, Murawski SA, Pope JG (1994) A global assessment of fisheries bycatch and discards, Vol 339. FAO, Rome

Amezcua-Linares F (1985) Recursos potenciales de peces capturados con redes camaroneras en al costa del Pacífico de México. In: Yañez-Arancibia A (ed) Recursos pesqueros potenciales de México: La pesca acompañante del camarón. UNAM, UPAL, INP, México, p 39-94

Arvizu-Martinez J (1987) Fishery activities in the Gulf of California, Mexico. CCOFI Rep 28:32-36

Badalamenti F, Anna GD, Pinnegar JK, Polunin NVC (2002) Size-related trophodynamic changes in three target fish species recovering from intensive trawling. Mar Biol 141:561-570

Beddington JR, Agnew DJ, Clark CW (2007) Current Problems in the Management of Marine Fisheries. Science 316:1713-1716

Broadhurst MK, Kennelly SJ (1994) Reducing the by-catch of juvenile fish (mulloway Argyrosomus hololepidotus) using square-mesh panels in codends in the Hawkesbury river prawn trawl fishery, Australia. Fish Res 19:321-331

Casey JM, Myers RA (1998) Near extinction of a large, widely distributed fish. Science 281:690-692

Caso ME (1976) El estado actual del estudio de los equinodermos de México. An Centr Cienc Mar Limnol Univ Nal Auton México 2:1-56

Charvet S, Statzner B, Usseglio-Polatera P, Dumont B (2000) Traits of benthic macroinvertebrates in semi-natural French streams: an initial application to biomonitoring in Europe. Freshw Biol 43:277-296

de Groot SJ (1984) The impact of bottom trawling on benthic fauna of the North Sea. Ocean Manag 9:177-190

de Juan S, Thrush SF, Demestre M (2007) Functional changes as indicators of trawling disturbance on a benthic community located in a fishing ground (NW Mediterranean Sea). Mar Ecol Prog Ser 334:117-129

FAO (2003) The ecosystem approach to fisheries. Technical guidelines for responsible fisheries. Report No. 4 (Suppl. 2), FAO, Rome

Folmer O, Pennington M (2000) A statistical evaluation of the design and precision of the shrimp trawl survey off West Greenland. Fish Res 49:165-178

Gislason H, Sinclair M, Sainsbury K, O'Boyle R (2000) Symposium overview: incorporating ecosystem objectives within fisheries management. ICES J Mar Sci 57:468-475

Gribble AN (2003) GBR-prawn: modeling ecosystem impacts of changes in fisheries management of the commercial prawn (shrimp) trawl fishery in the far northern Great Barrier Reef. Fish Res 65:493-506

Haddon M (2001) Modelling and quantitative methods in fisheries. Chapman \& Hall/CRC, Boca Raton, FL

Hall SJ (1999) The effect of fishing on marine ecosystems and communities. Blackwell, Oxford

Hall SJ, Mainprize B (2004) Towards ecosystem-based fisheries management. Fish Fish Ser 5:1-20

Hendrickx ME (1985) Diversidad de los macroinvertebrados bentónicos acompañates del camarón en el área del Golfo de California y su importancia como recurso potenciales. In: Yañez-Arancibia A (ed) Recursos pesqueros potenciales de México: la pesca acompañante del camarón. Universidad Nacional Autonoma de Mexico, Mexico City, p 95-148 (with English Abstract)

Hendrickx ME, van der Heiden A, Toledono-Granados A (1984) Results of the SIPCO Cruises (southern Sinaloa, Mexico) aboard the B/O 'El Puma'. Abundance and distribution of commercially exploitable molluscs. Rev Biol Trop 32:69-75

Hilborn R, Mangel M (1997) The ecological detective. Confronting models with data. Princeton Academic Press, Princeton, NJ

Hill BJ, Wassenberg TJ (1990) Fate of discards from prawn trawlers in Torres Strait. Aust J Mar Freshw Res 41:53-61

Hill A, Veale L, Pennington D, Whyte S, Brand A, Hartnoll R (1999) Changes in Irish Sea benthos: possible effects of 40 years of dredging. Estuar Coast Shelf Sci 48:739-750

INP (Instituto Nacional de la Pesca) (2007) Resultados de los muestreos de las poblaciones de Camarón, durante la veda del 2007 en el litoral del Pacífico. Direcciones generales de investigación pesquera en el Pacifico Norte y Sur. Instituto Nacional de la Pesca, Mexico City, available at www.inapesca.gob.mx/index.php?option=com_remository \&Itemid=19\&func $=$ startdown\&id $=78$

Jennings S, Dulvy NK (2005) Reference points and reference directions for size-based indicators of community structure. ICES J Mar Sci 62:397-404 
Jennings S, Kaiser MJ (1998) The effects of fishing on marine ecosystems. Adv Mar Biol 34:201-352

Kaiser MJ, Spencer BE (1994) Fish scavenging behavior in recently trawled areas. Mar Ecol Prog Ser 112:41-49

Kaiser MJ, Spencer BE (1995) Survival of by-catch from a beam trawl. Mar Ecol Prog Ser 126:31-38

Link JS (2005) Translating ecosystem indicators into decision criteria. ICES J Mar Sci 62:569-576

Link JS, Brodziak JKT, Edwards SF, Overholtz WJ and others (2002) Marine ecosystem assessment in a fisheries management context. Can J Fish Aquat Sci 59:1429-1440

Madrid-Vera J, Ruiz-Luna A, Rosado-Bravo I (1998) Fish from the continental shelf of Michoacán (México) and their regional relationships in the Mexican Pacific. Rev Biol Trop 46:267-276

Madrid-Vera J, Amezcua F, Morales-Bojórquez E (2007) An assessment approach to estimate biomass of fish communities from bycatch data in a tropical shrimp-trawl fishery. Fish Res 83:81-89

Magallón-Barajas FJ (1987) The Pacific shrimp fishery of Mexico. CCOFI Rep 28:43-52

Nance JM, Scott-Denton E (1996) Bycatch in the Gulf of Mexico shrimp fishery. In: Hancock DA, Smith DC, Grant A, Beumer JP (eds) Second World Fisheries Congress Proceedings. CSIRO, Melbourne, p 98-110

Neter J, Kutner MH, Nachtschien J, Wasserman W (1996) Applied linear statistical models, Vol III. McGraw-Hill/ Irwin, Chicago, IL

Nicholson MD, Jennings S (2004) Testing candidate indicators to support ecosystem-based management: the power of monitoring surveys to detect temporal trends in fish community metrics. ICES J Mar Sci 61:35-42

Pérez-Mellado J, Findley LT (1985) Evaluación de la ictiofauna acompañante del camarón capturado en las costas de Sonora y norte de Sinaloa, México. In: Yáñez-Arancibia A (ed) Recursos pesqueros potenciales de México: la pesca acompañante del camarón. Universidad Nacional Autónoma de México, Mexico City, p 201-254 (with English Abstract)

Pinnegar JK, Polunin NVC (2004) Predicting indirect effects of fishing in Mediterranean rocky littoral communities using a dynamic simulation model. Ecol Model 172: 249-267

Editorial responsibility: Jake Rice, Ottawa, Canada
Pitcher TJ, Preikhost D (2001) RAPFISH: a rapid appraisal technique to evaluate the sustainability status of fisheries. Fish Res 49:255-270

> Pope JG, MacDonald DS, Dann N, Rynolds JD, Jennings S (2000) Gauging the impact of fishing mortality on nontarget species. ICES J Mar Sci 57:689-696

Rochet MJ, Trenkel V (2003) Which community indicators can measure the impact of fishing? A review and proposals. Can J Fish Aquat Sci 60:86-89

Rochet MJ, Trenkel V, Bellail R, Coppin F and others (2005) Combining indicator trends to assess ongoing changes in exploited fish communities: diagnostic of communities off the coasts of France. ICES J Mar Sci 62:1647-1664

Shin YJ, Rochet MJ, Jennings S, Field JG, Gislason H (2005) Using size-based indicators to evaluate the ecosystem effects of fishing. ICES J Mar Sci 62:384-396

Stobutzki IC, Miller MJ, Jones P, Salini JP (2001) Bycatch diversity and variation in a tropical Australian penaeid fishery: the implications for monitoring. Fish Res 53: 283-301

Van der Heiden AM (1985) Taxonomía, biología y evaluación de la ictiofauna demersal del golfo de California. In: Yañez-Arancibia A (ed) Recursos pesqueros potenciales de México: la pesca acompañante del camarón. Universidad Nacional Autónoma de México, Mexico City, p 149-200

Van der Heiden AM, Findley LT (1988) Lista de los peces marinos del sur de Sinaloa, México. An Centr Cienc Mar Limnol Univ Nal Auton México 15:209-224

> Venzon DJ, Moolgavkor SH (1988) A method for computing profile-likelihood-based confidence intervals. Appl Stat 37:87-94

$>$ Wassenberg TJ, Hill BJ (1989) The effect of trawling and subsequent handling on the survival rates of the by-catch of prawn trawlers in Moreton Bay, Australia. Fish Res 7: 99-110

Ye E, Alsaffar AH, Mohammed HMA (2000) Bycatch and discards of the Kuwait shrimp fishery. Fish Res 45:9-19

Zar JH (1974) Biostatistical analysis. Prentice Hall, Upper Saddle River, NJ

Zetina-Rejón JM, Arreguin-Sanchez F, Chávez EA (2003) Trophic structure and flows of energy in the HuizacheCaimanero lagoon complex on the Pacific coast of Mexico. Estuar Coast Shelf Sci 57:803-815

Submitted: March 7, 2008; Accepted: November 24, 2009

Proofs received from author(s): February 26, 2010 